\title{
HIV-1 p24 derived epitopes modulate KIR2DL2-binding to HLA-Cw03
}

\author{
NH van Teijlingen ${ }^{1 *}$, C Körner ${ }^{2}$, L Fadda ${ }^{2}$, C Brander $^{3}$, MN Carrington ${ }^{4}$, D van Baarle ${ }^{1}$, M Altfeld $^{2}$ \\ From AIDS Vaccine 2012 \\ Boston, MA, USA. 9-12 September 2012
}

\section{Background}

Recent studies have suggested that HIV-1 can evade Natural Killer (NK)-cell-mediated immunity by mutating viral epitopes to enhance engagement of inhibitory Killer Ig-like receptors (KIRs) expressed on NK cells. However, the precise mechanisms modulating the interaction of inhibitory KIRs and their HLA class I ligands, and the role that HIV-1 epitopes might play in this interaction are not well understood. In this study we investigated whether HLA-Cw3-presented epitopes within HIV-1 p24 Gag can modulate binding of KIR2DL2, an inhibitory KIR, to HLA-Cw03.

\section{Methods}

Using tapasin-deficient 721.220 cell line expressing HLA-Cw*0304 we initially screened for HIV-1 peptides that stabilized HLA-Cw*0304 expression using 222 10mer peptides overlapping by 9 amino acids spanning the entire HIV-1 p24 Gag sequence. Peptides stabalizing HLA-Cw*0304 expression were thereafter investigated for their ability to facilitate binding of a KIR2DL2-IgG fusion construct.

\section{Results}

We identified several HIV-1 p24 epitopes that were able to stabilize HLA-Cw*0304 expression. A subset of these epitopes also allowed for binding of KIR2DL2. Currently we are investigating the consequences of KIR2DL2-binding to HLA class I presented HIV-1 epitopes for the antiviral function of primary NK cells from KIR2DL2+ individuals.

\section{Conclusion}

Taken together, these studies have identified epitopes within HIV-1 that enhance the binding of the inhibitory

${ }^{1}$ UMC Utrecht, Utrecht, the Netherlands

Full list of author information is available at the end of the article
NK cell receptor KIR2DL2 to its ligand HLA-Cw3, and are in line with recent data suggesting that the sequence of the HLA class I presented epitope has an important impact on the interaction between KIR and HLA class I (Boyington et al. Nature 2000, Vivian et al. Nature 2011).

\section{Author details}

${ }^{1}$ UMC Utrecht, Utrecht, the Netherlands. ${ }^{2}$ Ragon Institute of MGH, MIT and Harvard, Boston, MA, USA. ${ }^{3}$ IrsiCaixa (Institut de Recerca de la Sida),

Barcelona, Spain. ${ }^{4}$ National Cancer Institute at Frederick, Frederick, MD, USA.

Published: 13 September 2012

doi:10.1186/1742-4690-9-S2-P180

Cite this article as: van Teijlingen et al:: HIV-1 p24 derived epitopes modulate KIR2DL2-binding to HLA-Cw03. Retrovirology 2012 9(Suppl 2): P180.
Submit your next manuscript to BioMed Central and take full advantage of:

- Convenient online submission

- Thorough peer review

- No space constraints or color figure charges

- Immediate publication on acceptance

- Inclusion in PubMed, CAS, Scopus and Google Scholar

- Research which is freely available for redistribution
( Biomed Central

\section{() Biomed Central}

